\title{
The Santa Ninfa Cave (Belice Valley): hydrogeochemical features and relationships with neotectonics
}

\author{
Paolo Madonia ${ }^{*}, 1$, Giuliana Madonia ${ }^{2}$ \\ (1) Istituto Nazionale di Geofisica e Vulcanologia, Palermo, Italia \\ (2) Università degli Studi di Palermo, Dipartimento DiSTeM, Palermo, Italia, email giuliana.madonia@unipa.it
}

Article history: received July 25, 2019; accepted January 8, 2020

\begin{abstract}
The Santa Ninfa Cave (SNC) develops in an outcrop of Messinian gypsum, located in the heart of the zone struck by the 1968 seismic sequence of the Belice valley. It is composed of different levels of sub-horizontal galleries, the lowest of which is characterized by perennial flowing water, running along the water table. From the hydrogeological point of view, it configures as an open circuit, both inflowing and outflowing from/to neighboring aquifers. The geochemical facies of groundwater collected in the SNC is compatible with a meteoric recharge chemically interacting with evaporitic deposits. The most relevant geochemical feature is the mixing between a small tributary of sulfur water with the main stream flowing in the lowest passage. The mixing between groundwater of different origin, flowing in aquifers with different permeability, can give rise to geochemical transients linked to seismogenic processes. Under this light, SNC could be of potential interest in the framework of a monitoring system of neo-tectonic activity in southwestern Sicily.
\end{abstract}

Keywords: Earthquake source and dynamics; Fluid Geochemistry; Geomorphology; Groundwater processes; Stress.

\section{Introduction}

The Belice Valley, located in Western Sicily, was considered seismically quiescent until the 1968 seismic sequence [Barreca et al., 2014]. These earthquakes were positioned in a narrow, SSW-NNE oriented band, comprised between the towns of Montevago and Gibellina [Anderson and Jackson, 1987]. Data extracted from the INGV-Iside database (http://iside.rm.ingv.it) indicate that the most of the recent (since 1985) and more energetic (M>2.5) seismicity has occurred in the same area (Figure1).

A peculiar geological feature of this sector of the Belice Valley is the Santa Ninfa karst area, hosted in an outcrop of Messinian gypsum extending for about $15 \mathrm{~km}^{2}$ between the towns of Santa Ninfa and New Gibellina (Figure 1). It is characterized by the presence of a large number of caves, whose genesis and evolution is strongly controlled by tectonics [Madonia et al., 2017]. The most developed of these caves is known as Santa Ninfa Cave, hereafter referred as SNC (Figure2), located few kilometers NE of the city of Santa Ninfa and composed of multi-level galleries, the lowest of which is an active hydrogeological tunnel interconnected with the basal groundwater body. 


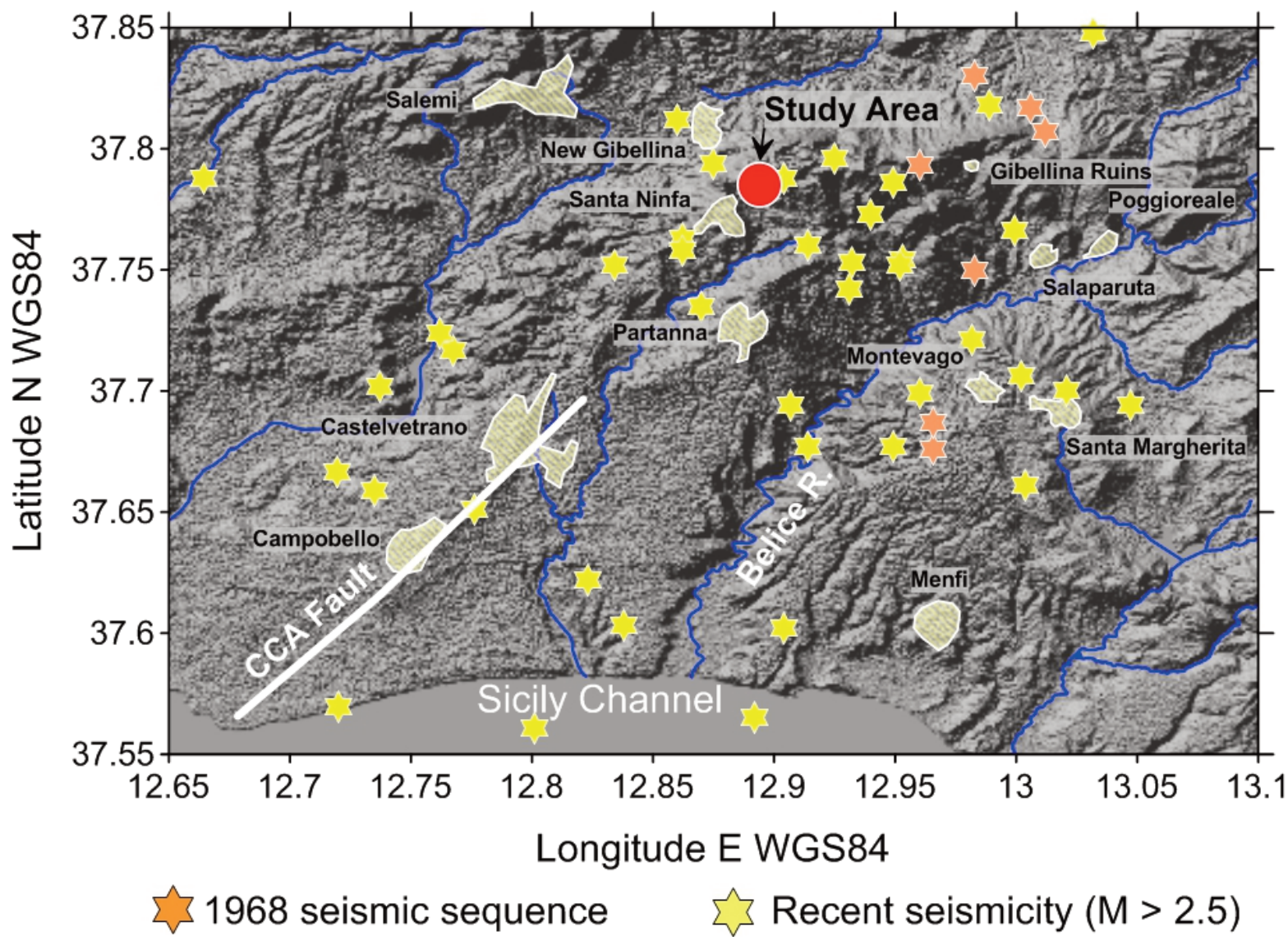

Figure 1. General map of the studied area showing locations of the 1968 earthquakes (orange stars) and epicenters of the more recent (since 1985) and energetic ( $\mathrm{M}>2.5$ ) seismicity (yellow stars).

Groundwater circulating in fracture networks where neotectonic processes take place are often affected by geochemical transients, as in the case of western Sicily. Favara et al. [2001] studied thermal springs in this area, including the site of Terme Acqua Pia (close to Montevago, Figure1), finding anomalies of temperature and concentration of dissolved ions in connection with the 1968 seismic sequence. These promising, preliminary results highlight the importance of investigating the relationship between geochemistry of groundwater and neotectonics, looking for possible indicators of seismogenic processes.

The Santa Ninfa karst aquifer is a good potential site to study these phenomena, because it is well geometrically delimited and located within a seismically active area. Its general hydro-geochemical features are discussed in another paper of this issue by Favara et al. Here we report in detail on SNC karst system, the role of tectonics in its genesis and development and the geochemical characters of groundwater flowing in this hydrogeological tunnel. We conclude discussing the possible role of this cave as a monitoring site for neotectonic activity in the Belice Valley.

\section{Area settings}

\subsection{Surface geology and geomorphology}

The Santa Ninfa area is located in the Belice Basin, a wedge-top basin individuated since at least the Messinian above the outer carbonate thrust system of the Maghrebian-Sicilian belt [Catalano et al., 1996; Vitale, 1997; Vitale and Sulli, 1997]. It is characterized by large Messinian gypsum outcrops, belonging to the Gessoso-solfifero Group, which lie above Upper Tortonian-Lower Messinian silico-clastic deposits (Terravecchia Fm.) and are overlain by Zanclean marly limestones (Trubi Fm.); these are in turn covered by Upper Pliocene clays and sandy marls (Marnoso 


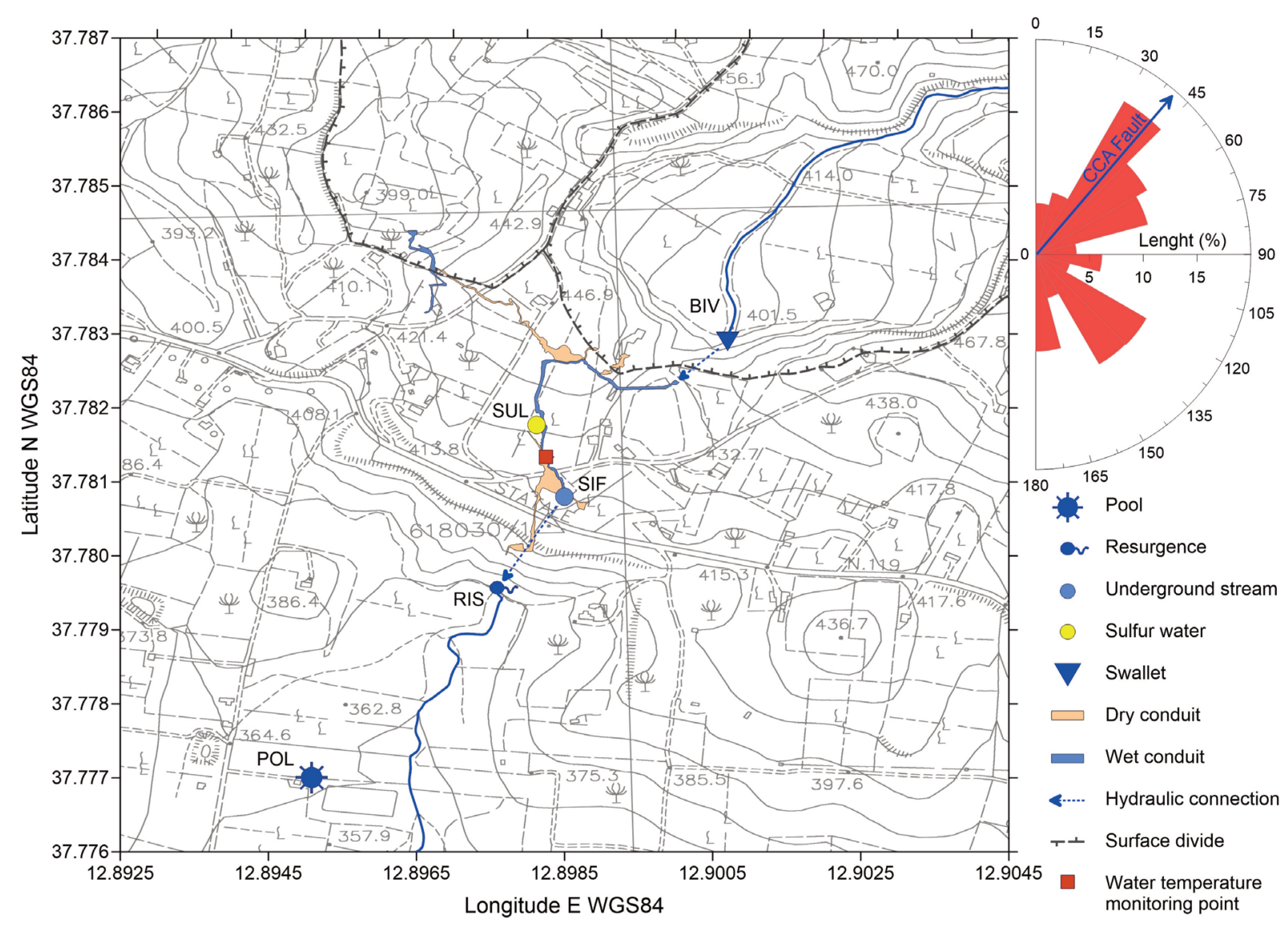

Figure 2. Detail of the Santa Ninfa Cave area with locations of water sampling points. On the right a polar diagram showing frequencies of orientation of the main karst galleries of the area (modified from Madonia et al., 2017) and the direction of the Castelvetrano-Campobello di Mazara Fault (CCA, after Barreca et al., 2014) is reported.

Arenacea del Belice Fm.), outcropping on the southern and western sector of the area. Gypsum consists mainly of selenite gypsum arranged in beds of different thickness, separated by thin clayey-marly levels, and secondarily by gypsum marls and re-deposited gypsum (gypsum rudite, gypsum-arenite, gypsum-siltite). Messinian grey marly and clayey deposits, containing thin clay-gypsum levels, outcrop laterally or above the gypsum units [Agostini and Cucchi, 1989]. The main structural lineaments refer to NE-SW, SW-NE and E-W high-angle faults, which favored lateral contact between the gypsum units and the younger clayey-marly deposits, displacing also the gypsum outcrops.

From the geomorphological point of view this area is characterized by a plateau, gently sloping southward and bordered to the north by elongated ENE-WSW and NW-SE fault line scarps. This plateau is articulated in different aligned gypsum reliefs, with altitudes ranging from $663 \mathrm{~m}$ to about $500 \mathrm{~m}$ a.s.l. The geomorphological setting is mainly influenced by karst processes, which favored the development of several caves and a large variety of surface landforms, as small sculptures in rock (karren), solution dolines (mainly point recharge dolines) and karst valleys. Dolines occupy the whole northern part of the plateau, forming a meshed polygonal system, typical of tropical regions. Sometimes aligned point recharge dolines, formed as a consequence of the upstream migration of swallets of small blind valleys, are recognizable; these alignments follow the pattern of old fluvial networks developed on the impervious cover, before gypsum was exposed by erosion processes [Agnesi et al., 1989; Sauro, 1996; De Waele et al., 2017].

The karst valleys are generally blind valleys, which may be entirely cut in gypsum or in clayey-marly rocks and end blindly at a gypsum threshold. The most significant is the Biviere valley, which feeds the SNC karst system. Spatial distribution of dolines and valley directions are often strongly correlated to the main structural features of the area. About 40 caves have been explored in the area, generally located at the downslope termination of blind valleys or at sink points at doline bottoms. Several small tectonic caves developed along open sub-vertical fractures, due to tension-release or gravitational processes. 


\section{Paolo Madonia et al.}

\subsection{The Santa Ninfa Cave (SNC)}

The SNC system is the most important of the area, both for its size and its morphological and speleogenetic features. It is an epigenic gypsum cave system, developed under an unconfined setting, consisting of a sink cave (accessible only for a few meters) that opens at the end of the Biviere Valley, a through-cave (SNC) about $1350 \mathrm{~m}$ long and $30 \mathrm{~m}$ deep, and a very small resurgence; the connection between these three cavities was verified by a tracer test carried out by the authors in 1985 and confirmed during a second experiment in 1986 [Chiesi et al., 1989].

SNC developed on at least three main levels of sub-horizontal galleries; vadose and epiphreatic features, paragenetic morphologies (eg.: significant ceiling half tubes on the roof) and collapse forms characterize the highest inactive passages. Here physical and chemical deposits are widespread. The lower gallery, connected to the higher level by a large collapse chamber, is characterized by perennial flowing water running along the water table, and epiphreatic morphologies. In the middle of this passage, the cave stream is fed by sulfur water from a lateral small tributary, whose capture appears to had happened around 2000-2500 years ago, as testified by: i) Presence of flowstones with corrosion forms up to $20 \mathrm{~cm}$ thick, generated by condensation-corrosion processes in presence of $\mathrm{H}_{2} \mathrm{~S}$ oxidized to $\mathrm{H}_{2} \mathrm{SO}_{4}$; a corrosion rates of $0.09 \mathrm{~mm}$ /year have been estimated for these forms, suggesting that the capture of sulfur water should have taken place during the last 2000-2500 years. ii) Occurrence of very thin (up to few millimeters) polymineral speleothems linked to the presence of $\mathrm{H}_{2} \mathrm{~S}$; their small thickness would indicate a very recent growth, not exceeding two thousand years. Moreover, the presence of sand deposits with man-made elements (e.g.: ceramic remains), which are older than the capture of the sulfur water by the underground river, seems to confirm this age (Bini et al., 1989). From the geomorphological and hydrogeological points of view, SNC is a multi-base level cave [sensu Calaforra and Gázquez, 2017], controlled by the fluctuation of the local base level under free aquifer hydrogeological conditions.

The SNC system is referred as a typical gypsum karst system under unconfined conditions, characterized by a main drainage tube developed along the water table, connecting directly sink points to a resurgence. Generally, these caves show linear or dendritic patterns, which adjust rapidly to the local base level and the available recharge [Forti \& Sauro, 1996; Klimchouk 1996; 2000]. Conduit systems are hierarchically organized to be similar to surface water drainage networks (Forti, 1993).

These patterns are related to the chemistry and kinetics of gypsum dissolution and to structural features of gypsum rocks, such as low primary permeability and low density of fissures (fractures or faults), common in the Messinian gypsum of Sicily and the Emilia Romagna Apennines [Forti and Rossi, 2003; Klimchouk 2000, Ferrarese et al., 2002; Pisani et al., 2019]. The high solubility of gypsum fosters its erosion by channeled flows, causing a generally fast evolution of underground passages. This fosters the rapid development of drainage tubes that directly connect in- and out-flow points, with consequent formation of very simple and linear cavities. Meanwhile, minor fractures not flown by groundwater tend to be sealed by both silt and clay, or by the deposition of gypsum driven by evaporation of saturated solutions during dry periods [Ferrarese et al., 2002; Forti and Rossi, 2003]. For these reasons, the speleogenetic evolution is very rapid along the main drainage path but extremely slow outside it [Forti and Rossi, 2003].

Caves formed in unconfined settings tend therefore to form strongly localized linear or dendritic systems, in relation to the high heterogeneity and extreme anisotropy of unconfined karst permeability. These caves receive a more or less concentrated recharge from the immediately overlying or adjacent areas. Conduit systems are hierarchically organized to effectively concentrate and laterally transmit flow in the down gradient direction [Klimchouk, 2005]. Karst aquifers transmissivity is generally high, whereas storage is low. Karst systems respond to major rain events with a flow-through hydraulics, and their related spring discharges tend to vary quickly [Forti, 1993; Klimchouk, 1996; 2000; 2005].

\section{Materials and methods}

Geochemical data here presented are from 5 sampling sites located at various hydraulic sections of the SNC hydrogeological tunnel, and in particular (Figure 2):

1) BIV is surface runoff collected at the entrance of the Biviere swallet, located at the end of the homonymous blind valley, and feeding the underground circulation system; 
2) SUL and SIF are samples from the underground stream flowing in the lowest gallery of SNC, collected after (SIF) the mixing with a lateral tributary from the hydrographic left (SUL);

3) RIS and POL are groundwater from the resurgence of SNC (RIS) and a pool (POL), located immediately downflow and formed by the intersection between the topographic and piezometric surfaces.

Geochemical information concerns concentrations of dissolved ions and gases. Data of RIS and POL are from the paper by Favara et al. [this issue], the other ones from the internal database of INGV, Sezione di Palermo, and refer to samples collected between 1997 and 2010.

Water samples used for the determination of dissolved major and trace elements were first filtered using 0.45 $\mu \mathrm{m}$ Millipore MF filter and then collected in LD-PE (low-density polyethylene) bottles for major element analyses, acidifying to ca $\mathrm{pH} 2$ the aliquot destined to cation determination with $\mathrm{HCl}$. All the analyses were carried out in the laboratories of INGV, Sezione di Palermo Untreated aliquots were stored for alkalinity determinations, made via titration with $\mathrm{HCl}(0.1 \mathrm{~N})$. Major ions were determined by ionic chromatography using a Dionex 2000i instrument. Samples for dissolved gas determinations were collected into sealed glass bottles, extracted and analyzed following the procedure described by Capasso and Inguaggiato [1998]. Gas chemical composition was measured using a Perkin Elmer Clarus 500 gas-chromatograph. All the data are presented in Table 1.

Continuous measurements (hourly frequency) of rainfall amount, external air and water temperature of the underground creek are from the database of the monitoring network of "Legambiente", the NGO responsible for the management of a Nature Reserve comprehending SNC.

\begin{tabular}{|c|c|c|c|c|c|}
\hline Sample & BIV & SUL & SIF & RIS & POL \\
\hline $\mathrm{Na}\left(\mathrm{mEq} \mathrm{L}^{-1}\right)$ & 3.1 & 5.8 & 3.7 & 4.0 & 4.9 \\
\hline $\mathrm{K}\left(\mathrm{mEq} \mathrm{L}^{-1}\right)$ & 0.1 & 0.3 & 0.2 & 0.1 & 0.2 \\
\hline $\mathrm{Mg}\left(\mathrm{mEq} \mathrm{L}^{-1}\right)$ & 4.8 & 11.3 & 5.6 & 6.1 & 5.9 \\
\hline $\mathrm{Ca}\left(\mathrm{mEq} \mathrm{L}^{-1}\right)$ & 31.3 & 30.0 & 33.8 & 34.1 & 35.0 \\
\hline $\mathrm{Cl}\left(\mathrm{mEq} \mathrm{L}^{-1}\right)$ & 3.4 & 4.4 & 3.7 & 3.3 & 4.0 \\
\hline $\mathrm{SO}_{4}\left(\mathrm{mEq} \mathrm{L}^{-1}\right)$ & 32.4 & 38.3 & 34.5 & 35.4 & 35.8 \\
\hline $\mathrm{HCO}_{3}\left(\mathrm{mEq} \mathrm{L} \mathrm{L}^{-1}\right)$ & 3.37 & 4.60 & 3.93 & 4.06 & 5.08 \\
\hline TDS $\left(\mathrm{mg} \mathrm{L}^{-1}\right)$ & 2680 & 3360 & 2894 & 2946 & 3098 \\
\hline $\mathrm{H}_{2}\left(\mathrm{cc} \mathrm{L}^{-1} \mathrm{STP}\right)$ & nd & 0.0032 & bdl & bdl & bdl \\
\hline $\mathrm{CH}_{4}\left(\mathrm{cc} \mathrm{L}^{-1} \mathrm{STP}\right)$ & nd & 0.0027 & 0.0041 & 0.0002 & 0.0042 \\
\hline $\mathrm{CO}_{2}\left(\mathrm{cc} \mathrm{L}^{-1} \mathrm{STP}\right)$ & nd & 41 & 52 & 8 & 29 \\
\hline
\end{tabular}

Table 1. Chemical composition of groundwater and dissolved gases sampled in the SNC system (nd is "not determined", bdl is "below detection limit"). 


\section{Tectonic and hydro-geochemical characteristics of the Santa Ninfa Cave system}

\subsection{Tectonic control on karst galleries development}

The SNC system, as other neighboring caves, is strongly controlled by the general geologic structure of the area [Cucchi, 1989], as generally occurs for other gypsum caves developed under unconfined settings in Sicily [Di Maggio et al., 2012; Madonia and Vattano, 2011] or in the Emilia Romagna Apennines [Pisani et al., 2019]. The main passages of SNC follow NNE-SSW and NW-SE sub-vertical joints and high angle faults, or develop along the strike of the bedding planes. Collapse chambers, connecting in some cases different levels of galleries, are located in correspondence of the intersection between different joint sets. In particular, about $700 \mathrm{~m}$ of the main subhorizontal passages develop as canyons or meanders along NNE-SSW sub-vertical fissures (fault or fracture planes). In some sectors of these galleries, small evidences of probably Quaternary strike-slip faults with right lateral motion were recognized [Cucchi, 1989]; clues of these movements are visible as stripes scratched on macro-crystals of gypsum, found on the right wall (hydrographic sensu) of the upper passage and marked by the growth of small individuals of re-crystalized gypsum.

The inner main passage and some lateral branches are correlated mainly to NW-SE and NNW-SSE and secondarily to NE-SW and E-W fractures. NNW-SSE and NE-SW high angle fractures and faults conditioned the development of the large chamber connecting the upper level to the active lower gallery. Signs of active tectonics are present in the cave sector where sulfur water appears [Bini, 1989].

It is worth of note that the dominant orientation of SNC passages, NNE-SSW, differs from the main direction of the other caves of the area, oriented SW-NE (Figure2). This direction coincides with the SW-NE alignment, found by Barreca and co-authors (2014) between Campobello di Mazara and Castelvetrano (CCA) by mean of interferometric, GPS, morphostructural and marine geophysical surveys, prosecuting offshore and characterized by aseismic deformation. Actually, other hydrogeological features of the SNC system are aligned with the SW-NE direction and, in particular, the main axis of the Biviere blind valley and the alignment connecting the BIV swallet, the underground sump SIF, the resurgence RIS and the pool POL (Figure 2). This observation suggests that the SNC passages could have developed following a network of discontinuities linked to a prior tectonic phase, mainly oriented NNE-SSW, to which neotectonic activity could have superimposed the SW-NE trend.

\subsection{Hydrogeological characteristics of SNC}

The relationships between surface runoff and groundwater circulation in the SNC system are illustrated in Figure 2. The main surface feature in hydrological connection with the underground system is the Biviere blind valley, whose runoff is drained by a swallet (BIV) that supplies the lowest of the karst galleries forming the cave. Another blind valley, located immediately NW of the Biviere, supplies a secondary branch of the underground system that in few tens of meters down-flow becomes inaccessible due to its small dimensions. The hydraulic connection between the Biviere swallow hole and the underground stream of SNC was verified during a tracing experiment, made by the authors using sodic fluorescein, carried out in 1985. During the same experiment, the connection between the down-flow termination of the hydraulically active part of the cave and the resurgence RIS was also proven. Another relevant feature is the small inlet of the main stream, located at its hydrographic right at about the mid of its route, characterized by sulfur water.

Although the hydraulic connection among the Biviere blind valley, the underground stream of the cave and the resurgence was proven, this system is interconnected with the general groundwater flow of the area anyway. Madonia [2001] measured in November 1997 the flow rate at the inlet of the swallet BIV and at the outlet RIS, finding values equal to 0.3 and $2.5 \mathrm{~L} \mathrm{~s}^{-1}$, respectively. Since the output from the resurgence was about one order of magnitude higher than the input from the Biviere, a significant contribution of groundwater from adjacent aquifers was invoked. On the contrary, results from the hydrological balance calculation demonstrated that the average annual input from the Biviere is about $900,000 \mathrm{~m}^{3}$, while the corresponding output from RIS is about $80,000 \mathrm{~m}^{3}$, i.e. one order of magnitude lower. This fact demonstrates that the most of the surface runoff from the Biviere outflows toward aquifers adjacent to the SNC, although in particular conditions, as in November 1997, these aquifers feed the 


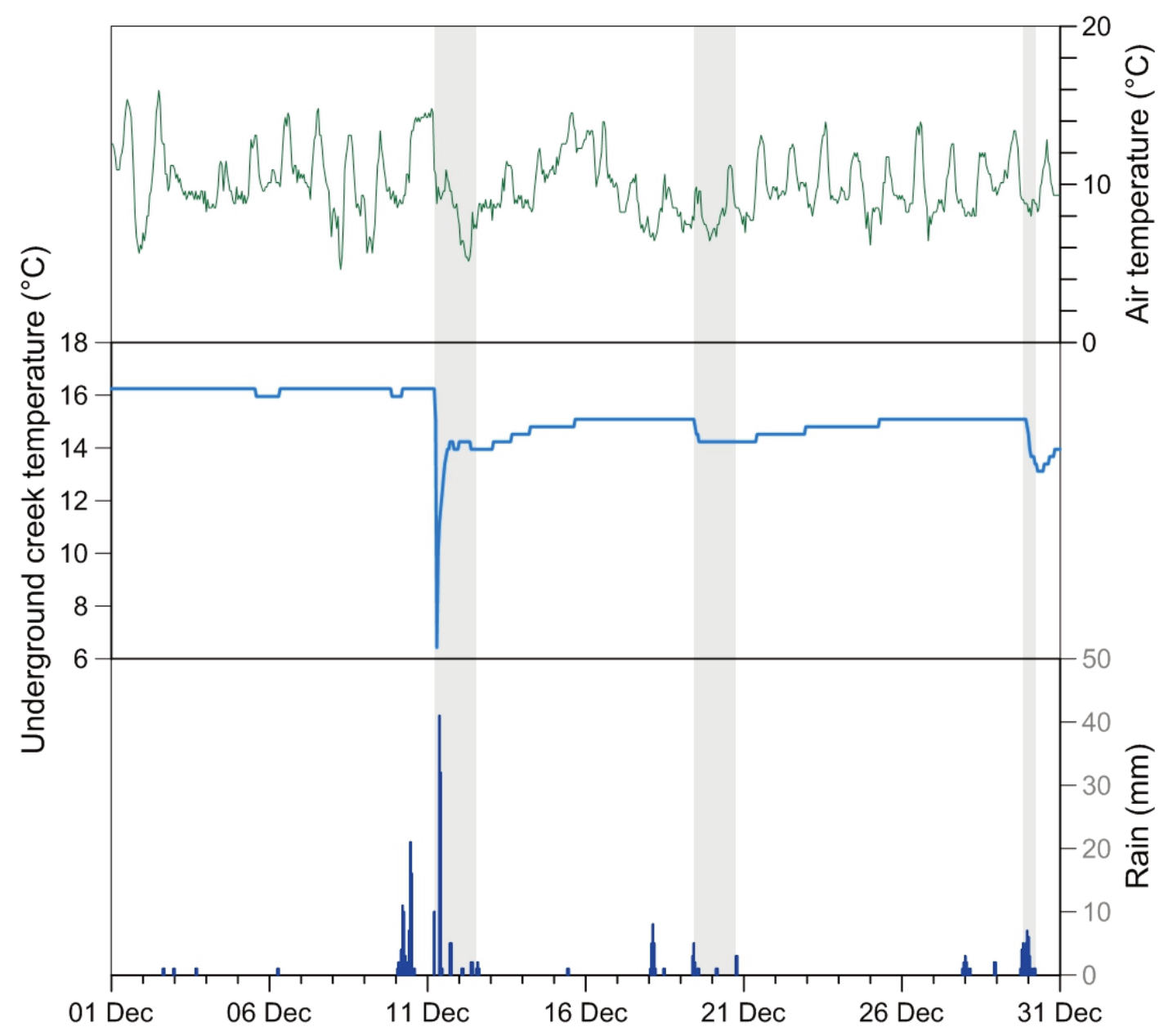

Figure 3. From the top to the bottom, hourly values of air temperature, water temperature of the underground creek of SNC, rainfall amount. Grey bands individuate decreases of water temperature following rainfall events. Data of air temperature and rainfall amounts were acquired in the meteorological station located few kilometers apart SNC.

SNC circulation system. In conclusion, the SNC is an open hydrogeological circuit both inflowing and outflowing from/to the wider circulation system of groundwater in the area.

The graph in Figure 3 shows hourly data of water temperature of the underground stream flowing in SNC, compared to air temperatures and rainfall amounts, giving interesting insights on the relationship between flow rate transients following rainfall events and the basal flow of the creek. The three grey bands mark three episodes of decrease of water temperature strictly following rainfalls, occurred on 11, 20 and 31 December 2008, respectively. Drops of water temperature indicate that surface runoff caught by the swallow hole, cooler than the basal flow, immediately reached the stream that incremented its flow rate. The mixing of water at different temperatures confirms that, as previously discussed, the hydraulic regime of the SNC underground stream is due to the combination of different inflows.

\subsection{Geochemistry of groundwater}

Chemistry of groundwater from SNC is shown in the Langelier-Ludwig diagram of Fig. 4, used for classifying water samples expressing their composition in terms of relative abundances of the main cations ( $\mathrm{Na}, \mathrm{K}, \mathrm{Ca}, \mathrm{Mg})$ and anions $\left(\mathrm{Cl}, \mathrm{SO}_{4}, \mathrm{CO}_{3}, \mathrm{HCO}_{3}\right)$ present in natural waters; assuming that the sum of all the cations is identical to that one of the anions, the relative weights are $50 \%$ each. Usually cations are divided in the couples $\mathrm{Na}-\mathrm{K}$ and $\mathrm{Ca}-\mathrm{Mg}$, 
Paolo Madonia et al.

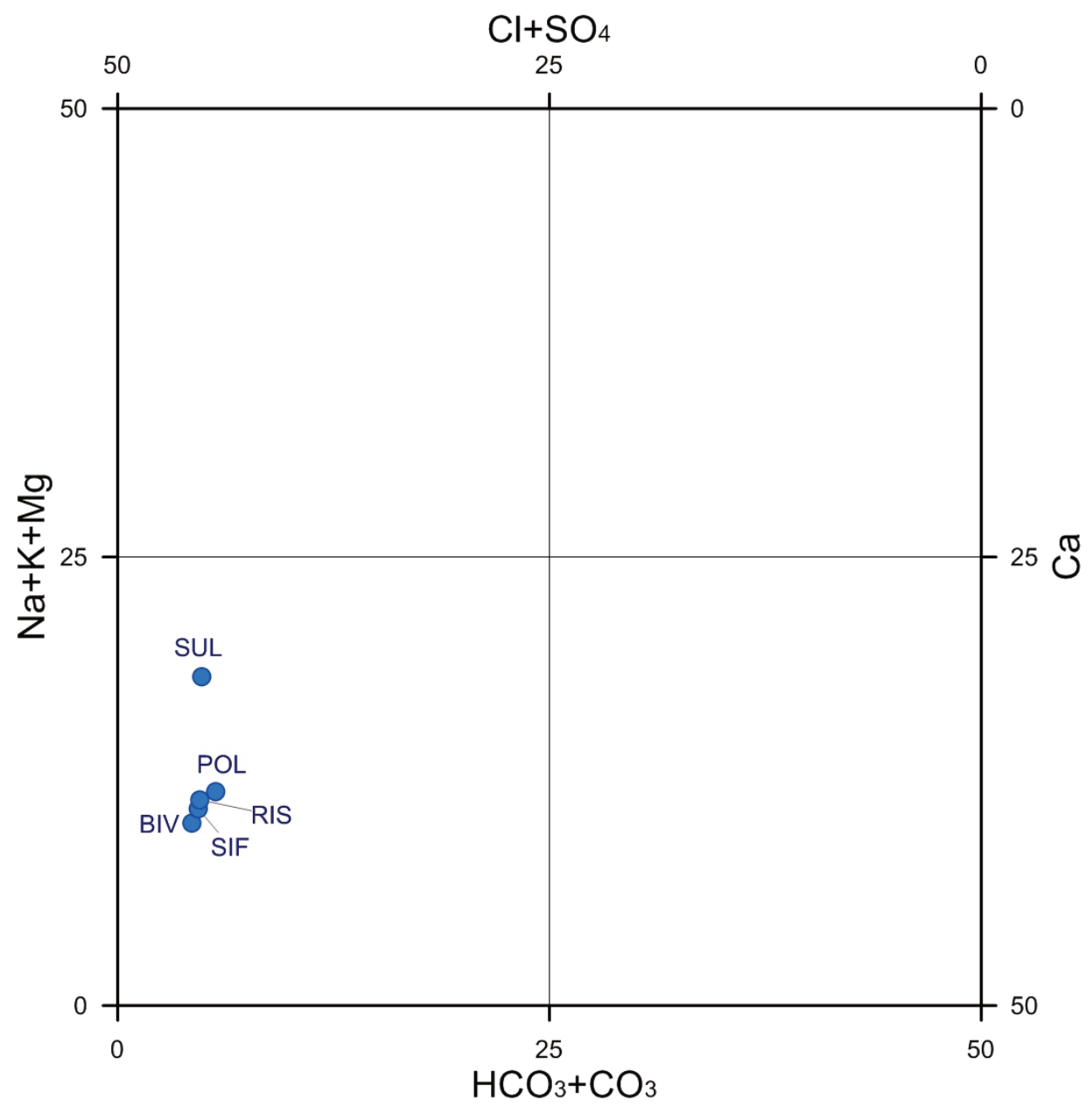

Figure 4. Langelier-Ludwig diagram showing the geochemical classification of water samples collected in the SNC area.

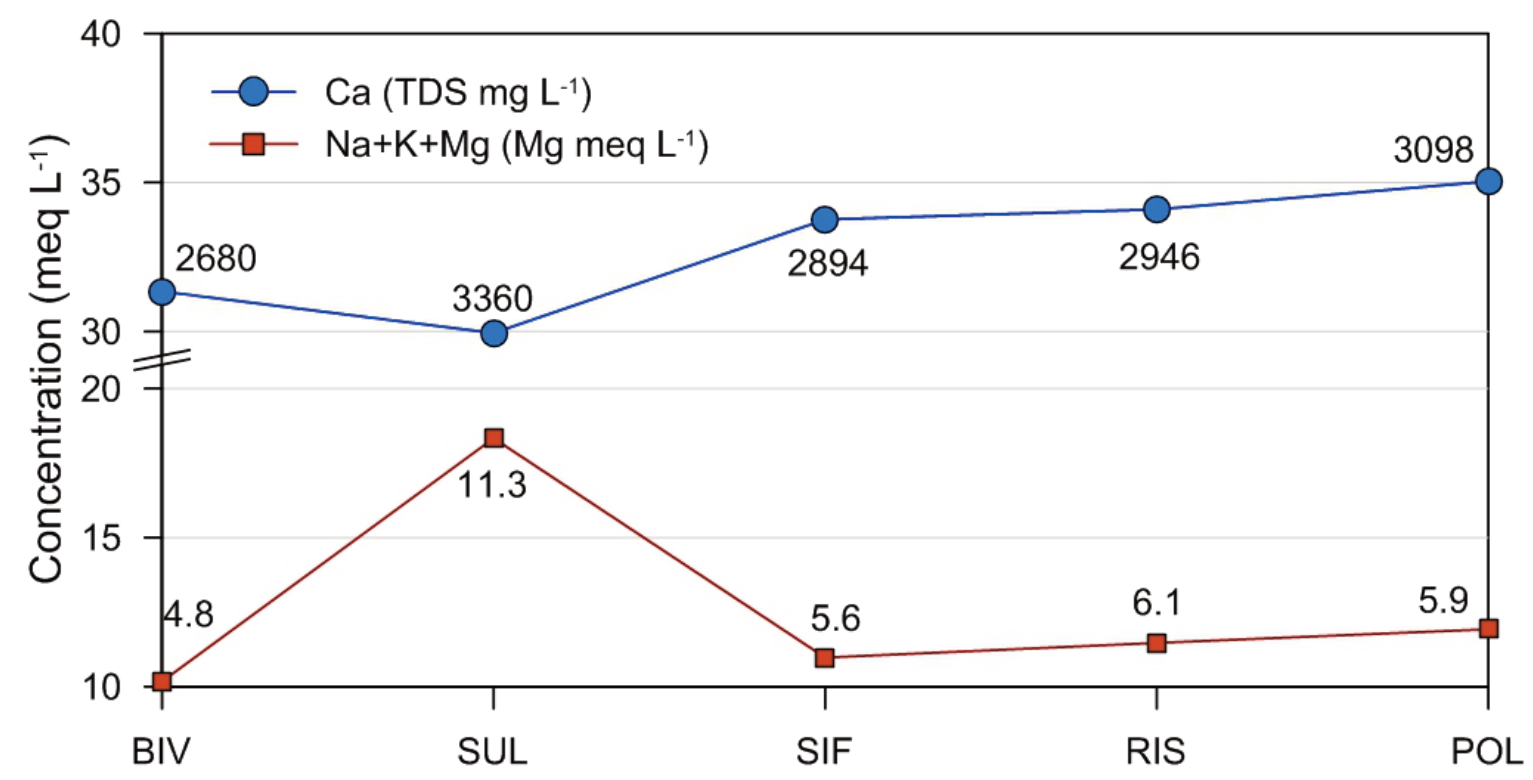

Figure 5. Concentrations of $\mathrm{Ca}$ (light blue circles) and $\mathrm{Na}+\mathrm{K}+\mathrm{Mg}$ (orange squares) in groundwater samples. Numbers associated to the $\mathrm{Ca}$ and $\mathrm{Na}+\mathrm{K}+\mathrm{Mg}$ curves are TDS and $\mathrm{Mg}$ concentrations of the samples, respectively. 
but, since we are studying an aquifer where the main ion source is the dissolution of gypsum $\left(\mathrm{CaSO}_{4} \cdot 2 \mathrm{H}_{2} \mathrm{O}\right)$, we modified the standard representation coupling $\mathrm{Mg}$ to $\mathrm{Na}-\mathrm{K}$. All the data fall in the lower left quadrant, representative of the chloride-sulfate-earth-alkaline waters, typical of gypsum aquifers. Despite this generally uniform composition, small variations (few per cents) are observed: moving down-flow from the sink hole (BIV) to the pool (POL), groundwater exhibits a progressive relative enrichment in carbonate species, while the inlet (SUL) is characterized by a relative increment in $\mathrm{Na}-\mathrm{K}-\mathrm{Mg}$ concentrations with the anion composition remaining substantially invariant.

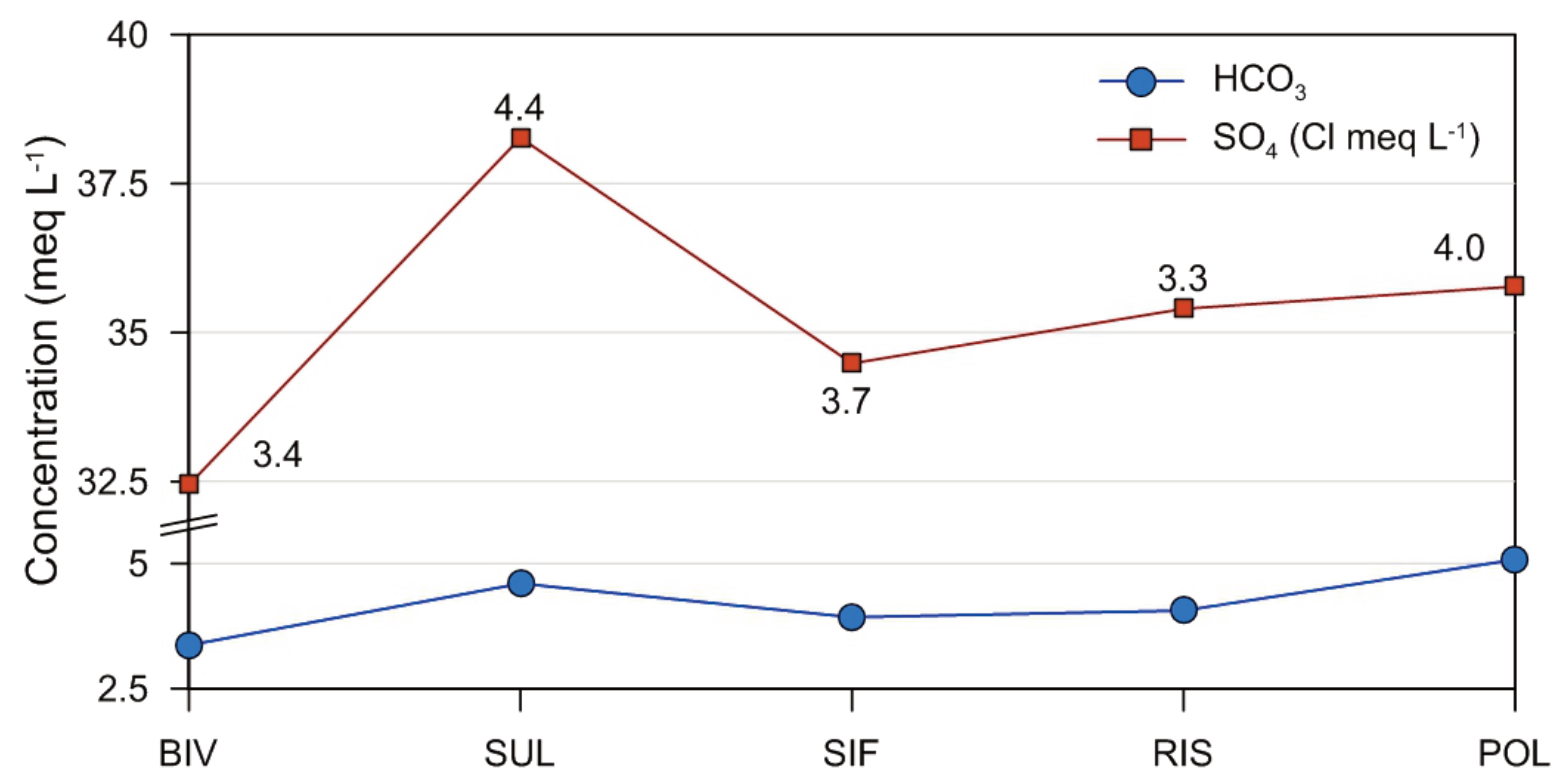

Figure 6. Concentrations of $\mathrm{HCO}_{3}$ (light blue circles) and $\mathrm{SO}_{4}$ (orange squares) in groundwater samples. Numbers associated to the $\mathrm{SO}_{4}$ curve is $\mathrm{Cl}$ concentration of the samples.

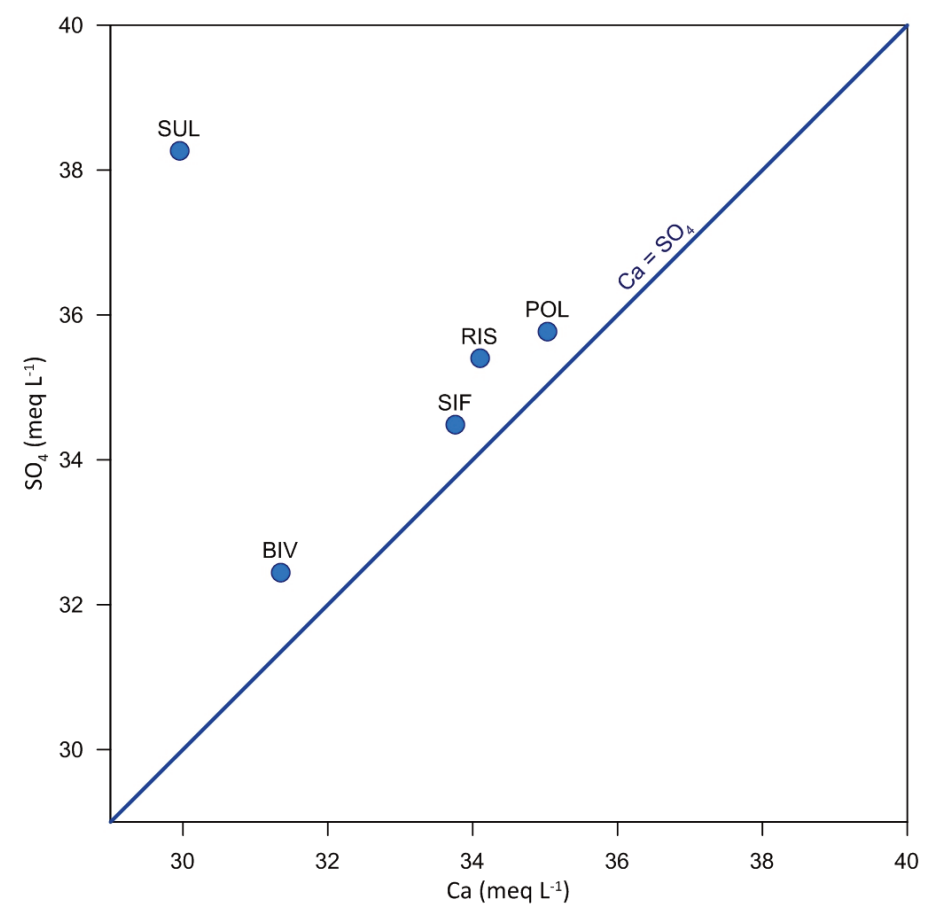

Figure 7. Scatterplot of $\mathrm{Ca}$ vs $\mathrm{SO}_{4}$ concentrations in the samples. The $\mathrm{Ca}_{-} \mathrm{SO}_{4}$ line, expressing the stoichiometric ratio of gypsum/anhydrite dissolution is also shown. 


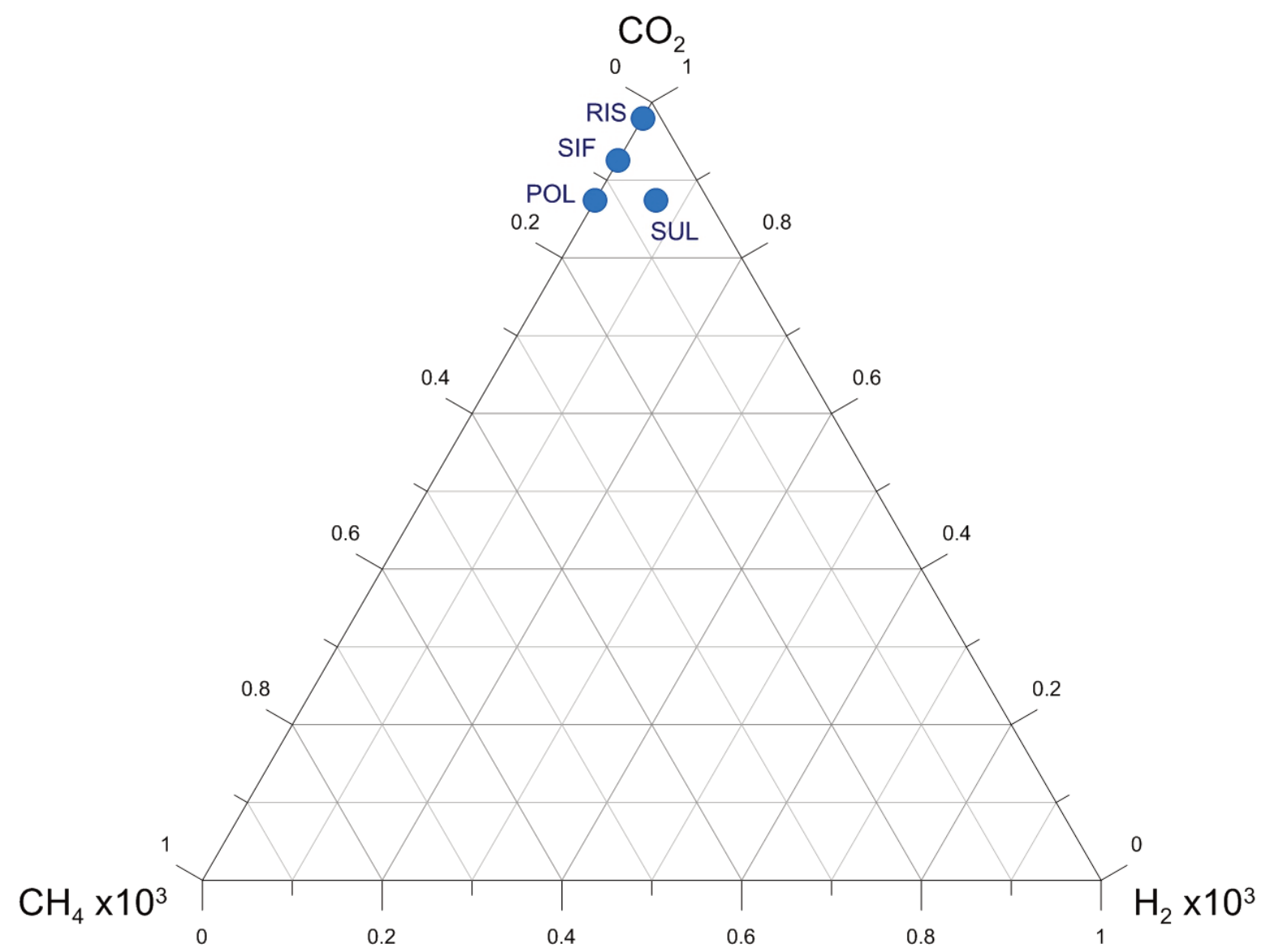

Figure 8. Ternary diagram showing the concentrations of dissolved gases expressed as $\mathrm{CO}_{2}, \mathrm{H}^{2} \mathrm{x} 10^{3}, \mathrm{CH}^{4} \times 10^{3}$

Since the Langelier-Ludwig diagram adopts relative weights, further graphs are needed for individuating which are the chemical species responsible for the observed variations. Exploring first cations, we found in Fig. 5 concentration variations of $\mathrm{Ca}$, with labels indicating the Total Dissolved Solids (TDS), and $\mathrm{Na}+\mathrm{K}+\mathrm{Mg}$, with labels referred to Mg. We observe a progressive increment in TDS, with a maximum difference between BIV and SIF after the mixing with the inlet SUL, which is the sample with the highest $\left(3360 \mathrm{mg} \mathrm{L}^{-1}\right.$ ) TDS value. The two groups of cations show similar absolute variations along the main stream, while the different composition of SUL is determined by a modest decrement of $\mathrm{Ca}$ accompanied by a more than doubled concentration of Mg. A similar behavior is observed for anions (Figure 6), where the increment in SUL is mainly due to higher $\mathrm{SO}_{4}$ concentrations. It is worth of note, as shown in Figure 7, that the parallel Ca decrement and $\mathrm{SO}_{4}$ increment observed in SUL determine a huge deviation of this sample from the line expressing the stoichiometric equilibrium of gypsum dissolution (1:1), indicating that a supplementary $\mathrm{SO}_{4}$ source is involved.

Further information is given by the ternary graph of Figure 8, illustrating the relative abundance of three dissolved gaseous species, $\mathrm{CO}_{2}, \mathrm{CH}_{4}$ and $\mathrm{H}_{2}$, whose presence has been determined in the analyzed samples (no data for BIV). The dominant species is $\mathrm{CO}_{2}$, with small percentages of $\mathrm{CH}_{4}$ increasing from RIS to POL, analogously to what observed for ion concentrations. The other similarity with the behavior of dissolved ions is the marked difference of SUL, which is the only sample showing the presence of dissolved molecular hydrogen $\left(\mathrm{H}_{2}\right)$, indicating that reducing conditions characterize water flowing in the inlet.

The general geochemical behavior of the sampled groundwater, depicted by the graphs previously described, indicates a normal process of dissolution of evaporitic deposits, dominated by gypsum/anhydrite eventually associated to other K-alkaline salts and clay minerals. The TDS content increases from BIV to POL (Figure 5), coherently with the chemical interaction with the hosting rocks of meteoric water initially dominated by the surface runoff caught by the swallow hole (BIV), mixing with progressively increasing amounts of groundwater circulating in minor order discontinuities, fractures and small karst conduits, which can be referred to as "Background 
Groundwater Discharge" (BGD). With respect to the surface runoff sampled in BIV, BGD is characterized by a more advanced water/rock interaction stage, fostered by higher residence times, larger water/rock exchange surfaces, typical of small voids, and relevant contributions of organic $\mathrm{CO}_{2}$ from soil respiration. Clues of these processes are also found in the trend shown in the Langelier-Ludwig diagram of Figure 4, indicating that from BIV to POL groundwater is progressively enriched in carbonate species (mostly $\mathrm{HCO}_{3}{ }^{-}$, due to $\mathrm{pH}$ conditions) and $\mathrm{Na}+\mathrm{K}+\mathrm{Mg}$. Carbonates come from the dissolution of organic carbon dioxide, whereas the most probable source for the cations are the ionic exchange processes with clays, which are largely present in the minor discontinuity network.

A chemical fingerprint more shifted toward the interaction processes with clays is found in SUL, which is the sole sample markedly different from all the others. This difference is due to higher $\mathrm{Mg}$ (Figure 5) and $\mathrm{SO}_{4}$ (Figures 6-7) contents, which can be referred to ion exchange with clay minerals, for the cation, and oxidation to sulfate of $\mathrm{H}_{2} \mathrm{~S}$ produced during the degradation of the rich (vegetal) organic matter content of clays. The typical reducing conditions associated to organic matter degradation are further pointed out by the presence of dissolved $\mathrm{H}_{2}$, which is present only in SUL sample (Figure 8).

As a comprehensive remark, the hydro-geochemical fingerprint of groundwater circulating in SNC identifies a meteoric system hosted in an evaporitic hydrogeological complex, rich in clay minerals, with no evidence of deep fluid contributions.

\section{Possible relevance of the SNC system in the monitoring of neotectonic activity}

The ultimate aim of this work is the evaluation of SNC as a possible site for the monitoring of neotectonic activity in this sector of the Belice Valley.

Previous studies identified inside SNC some morphologies linked to active tectonics Cucchi, 1989]. Moreover, the basal groundwater circulation in SNC seems influenced by the most recent tectonics, as indicated by the alignment of its main active hydrogeological features. In fact, the main axis of the Biviere blind valley and the swallet (BIV), the internal sump (SIF), the resurgence (RIS) and the pool (POL), form a SW-NE alignment coinciding with that one (CCA) found by Barreca et al. [2014] between Campobello di Mazara and Castelvetrano (Figure 2).

The geochemical characteristics of groundwater collected in the SNC system are compatible with an aquifer fed by a meteoric recharge and chemically interacting with evaporitic deposits; this chemical fingerprint finds analogies in what observed in other gypsum caves in northern Italy [Vigna et al., 2017]. No evident clues of mixing with deeper fluids have been found. A different chemical facies, influenced by the interaction with sulfur species, has been detected in the tributary of the underground stream (SUL, Figure 2), but its origin can be related to the degradation of the organic matter content of clays partially filling the small discontinuities through which this water flows. Soil $\mathrm{CO}_{2}$ flux data collected by Camarda et al. (this issue) in this area support this hypothesis, even though these authors do not exclude at all that the gases released by the soil could receive minor contributions of fluids of deeper origin.

Even in absence of a clear contribution of deep fluids carried through tectonic discontinuities, the simple mixing between shallow groundwater of different origin, with a different chemical character and circulating in aquifers with a different permeability, could be interesting in the monitoring of neotectonic activity. This is the case of SNC, where the tributary SUL is chemically different with respect to groundwater collected in the underground stream and circulates in minor order discontinuities, partially filled with clays, and therefore characterized by a much lower permeability than the wide karst conduits hosting the stream.

Stress field variations associated to seismogenic processes can significantly affect the permeability linked to the small voids through which the sulfur water circulates, whereas higher order discontinuities, as those related to the flow of the underground stream, should remain unaffected. Differential permeability variations lead to different mixing proportions, generating geochemical transients linked to seismogenic processes, as observed in other geological contexts where geofluids with different physic-chemical characters mix [Favara et al., 2007; Madonia et al., 2013]. This consideration remarks the potential interest of SNC in the framework of a monitoring system of neo-tectonic activity in southwestern Sicily. The presence of a cave partially developing along a fault plane, and accessible by humans, could allow the implementation of an observational system that extends to the "Inside Fault Observatory" the "Near Fault Observatory" concept already applied in other seismically active areas of Italy, as the High Tevere valley [Chiaraluce et al., 2014]. 


\section{Paolo Madonia et al.}

\section{References}

Agnesi, V., T. Macaluso, M. Meneghel, and U. Sauro (1989). Geomorfologia dell'area carsica di Santa Ninfa (in Italian), in I gessi di Santa Ninfa Agnesi V. and T. Macaluso (Editors.), Mem. Ist. Ital. Speleol., 2(3), 23-48.

Agostini, A. and F. Cucchi (1989). Caratteristiche geologiche dell'area carsica di Santa Ninfa (in Italian), in I gessi di Santa Ninfa Agnesi V. and T. Macaluso (Editors.), Mem. Ist. Ital. Speleol., 2(3), 15-22.

Anderson, H. and J. Jackson (1987). Active tectonics of the Adriatic Region, Geophys. J. R.Astr. Soc., 91, 937-983. Barreca, G., V. Bruno, C. Cocorullo, F. Cultrera, L. Ferranti, F. Guglielmino, L. Guzzetta, M. Mattia, C. Monaco and F. Pepe (2014). Geodetic and geological evidence of active tectonics in south-western Sicily (Italy), J. Geodyn., 82, 138-149, http://dx.doi.org/10.1016/j.jog.2014.03.004.

Bini, A. (1989). Morfologia e sedimentologia ipogea delle cavità di Santa Ninfa (in Italian), in I gessi di Santa Ninfa Agnesi V. and T. Macaluso (Editors.), Mem. Ist. Ital. Speleol., 2(3), 101-135.

Bini, A., F. Cucchi, P. Forti and M. Panzica La Manna (1989). Evoluzione speleogenetica con particolare riguardo alla Grotta di Santa Ninfa (in Italian), in I gessi di Santa Ninfa Agnesi V. and T. Macaluso (Editors.), Mem. Ist. Ital. Speleol., 2 (3), 161-167.

Calaforra, J.M. and F. Gàzquez (2017). Gypsum speleogenesis: a hydrogeological classification of gypsum caves. Int. J. Speleol., 46, 251-265.

Camarda M., S. De Gregorio S., R. M. R. Di Martino, R. Favara and V. Prano (this issue). Relationships between soil $\mathrm{CO}_{2}$ flux and tectonics structures in SW Sicily.

Capasso, G. and S. Inguaggiato (1998). A simple method for the determination of dissolved gases in natural waters. An application to thermal waters from Vulcano Island. Appl. Geochem., 13, 631-642.

Catalano R., P. Di Stefano, A. Sulli and F.P. Vitale (1996). Paleogeography and structure of the central Mediterranean: Sicily and its offshore area. Tectonophysics, 260, 291-323.

Chiaraluce L., A. Amato, S. Carannante, V. Castelli, M. Cattaneo, M. Cocco, C. Collettini, E. D’Alema, R. Di Stefano, D. Latorre, S. Marzorati, F. Mirabella, G. Monachesi, D. Piccinini, A.Nardi, A. Piersanti, S. Stramondo and L. Valoroso (2014). The Alto Tiberina Near Fault Observatory (northern Apennines, Italy), Ann. Geophys-Italy, 57(3), S0327, DOI 10.4401/ag-6426.

Chiesi, M., P. Forti, and M. Panzica La Manna (1989). Le esplorazioni speleologiche dell'area carsica di Santa Ninfa, in I gessi di Santa Ninfa Agnesi V. and T. Macaluso (Editors.), Mem. Ist. Ital. Speleol., 2(3), 85-92.

Cucchi, F. (1989). Analisi delle caratteristiche morfostrutturali delle cavità dell'area di Santa Ninfa (in Italian), in I gessi di Santa Ninfa Agnesi V. and T. Macaluso (Editors.), Mem. Ist. Ital. Speleol., 2(3), 93-100.

De Waele, J., L. Piccini, A. Columbu, G. Madonia, M. Vattano, C. Calligaris, I.M. D’Angeli, M. Parise, M. Chiesi, M. Sivelli, B. Vigna, L. Zini, V. Chiarini, F. Sauro, R.N. Drysdale, and P. Forti (2017). Evaporite karst in Italy: a review. Int. J. Speleol., 46 (2), 137-268.

Di Maggio, C., G. Madonia, M. Parise, and M. Vattano (2012). Karst of Sicily and its conservation, J. Cave Karst Stud., 74(2), 157-172.

Favara, R., F. Grassa, S. Inguaggiato and M. Valenza (2001). Hydrogeochemisty and stable isotopes of the thermal springs: earthquake-related chemical changes along Belice Fault (Western Sicily), Appl. Geoc., 00, 1-17.

Favara, R., F. Grassa, P. Madonia and M. Valenza (2007). Flow Changes and Geochemical Anomalies in Warm and Cold Springs Associated with the 1992-1994 Seismic Sequence at Pollina, Central Sicily, Italy, Pure Appl. Geophys., 1-20.DOI 10.1007/s00024-007-0283-7.

Favara, R., M. Cangemi, and F. Grassa (this issue). Chemical and isotopic signature of groundwater in the Santa Ninfa karst system and possible inferences on neotectonics.

Ferrarese, F., T. Macaluso, G. Madonia, A. Palmeri and U. Sauro (2002). Solution and recrystallization processes and associated landforms in gypsum outcrops of Sicily, Geomorphology, 49(1-2), 25-43.

Forti, P. (1993). Karst evolution and water circulation in gypsum formations. Proceedings of the International Symposium on Water Resources in Karst with Special Emphasis in Arid and Semi-arid Zones, 23-26 Oct. 1993, Shim, Iran,791-801.

Forti P. and A. Rossi (2003). Il carsismo ipogeo nei gessi italiani (in Italian), Mem. Ist. Ital. Speleol., II (14), 65-87.

Forti, P. and U. Sauro (1996). Gypsum karst of Italy, Int. J. Speleol., 25 (3-4), 239-250.

Klimchouk, A. B. (1996). Hydrogeology of gypsum formation, Int. J. Speleol., 25(3-4), 83-89.

Klimchouk, A.B. (2000). Speleogenesis in Gypsum, in Speleogenesis: Evolution of karst aquifers A. Klimchouk, D. 
Ford, A. Palmer and W. Dreybrodt (Editors), National Speleological Society, Huntsville, USA, 431-442.

Klimchouk, A. B. (2005). Subsidence hazards in different types of karst: evolutionary and speleogenetic approach, Environ. Geol., 48, 287-295.

Madonia, G. and M. Vattano (2011). New knowledge on the Monte Conca gypsum karst system (central-western Sicily, Italy), Acta Carsologica, 40, 53-64.

Madonia, P. (2001). Problematiche cartografiche ed idrogeologiche relative alla riperimetrazione della riserva naturale “Grotta di Santa Ninfa” (in Italian). Nat. Sicil., S IV, XXV (Suppl.), 227-236.

Madonia P., P. Cusano, I.S. Diliberto and M. Cangemi (2013). Thermal anomalies in fumaroles at Vulcano island (Italy) and their relationship with seismic activity, Phys. Chem. Earth, 63, 160-169.

Madonia, P., M. Bracci, M. Cangemi, G. Casamento and F. P. Di Trapani (2017). Geo-datasets ed eterogeneita delle fonti cartografiche originarie: il caso del S.I.T. delle cavita naturali nell'area della Riserva Naturale Integrale “Grotta di Santa Ninfa” (TP) (in Italian), Atti XXI Conferenza Nazionale ASITA, Salerno, 21-23 November 2017.

Pisani, L., M. Antonellini and J. De Waele (2019). Structural control on epigenic gypsum caves: evidences from Messinian evaporites (Northern Apennines, Italy). Geomorphology, 332(1), 170-186.

Sauro, U. (1996). Geomorphological aspects of gypsum karst, with special emphasis on exposed karst, Int. J. Speleol., 25 (3-4), 105-126.

Vigna, B., I. M. D’Angeli, A. Fiorucci and J. De Waele (2017). Hydrogeological flow in gypsum karst areas: some examples from northern Italy and main circulation models, Int. J. Speleol., 46(2) 205-217.

Vitale, F. P. (1997). The Belice and the Menfi Basins: sequence stratigraphy and evolution during the Pliocene and the Early Pleistocene, in Field workshop in Western Sicily R. Catalano (Editor), Eurobasin Conference, Guidebook, 48-58.

Vitale, F. P. and A. Sulli (1997). The regional pattern of the Belice and Menfi basins: a deep geologic profile, in Field workshop in Western Sicily R. Catalano (Editor), Eurobasin Conference, Guidebook, 59-69. 